This is an electronic reprint of the original article. This reprint may differ from the original in pagination and typographic detail.

Author(s): Riivari, Elina; Lämsä, Anna-Maija; Kujala, Johanna; Heiskanen, Erika

Title: $\quad$ The ethical culture of organisations and organisational innovativeness

Year: $\quad 2012$

Version:

Please cite the original version:

Riivari, E., Lämsä, A.-M., Kujala, J., \& Heiskanen, E. (2012). The ethical culture of organisations and organisational innovativeness. European Journal of Innovation Management, 15(3), 310-331. https://doi.org/10.1108/14601061211243657

All material supplied via JYX is protected by copyright and other intellectual property rights, and duplication or sale of all or part of any of the repository collections is not permitted, except that material may be duplicated by you for your research use or educational purposes in electronic or print form. You must obtain permission for any other use. Electronic or print copies may not be offered, whether for sale or otherwise to anyone who is not an authorised user. 


\title{
The ethical culture of organisations and organisational innovativeness
}

\author{
Elina Riivari ${ }^{1}$ \\ University teacher \\ University of Jyväskylä, Open University \\ P.O. Box 35 \\ FIN-40014 University of Jyväskylä \\ Finland \\ Email: elina.riivari@jyu.fi \\ Elina Riivari is a teacher of management and leadership at the University of Jyväskylä, Open \\ University.
}

Anna-Maija Lämsä

Professor

University of Jyväskylä

School of Business and Economics,

P.O. Box 35

FIN-40014 University of Jyväskylä

Finland

Email: anna-maija.lamsa@jyu.fi

Anna-Maija Lämsä is a professor of human resource management at the University of Jyväskylä, School of Business and Economics.

\section{Johanna Kujala}

Professor

University of Tampere

School of Economics and Business Administration

FIN-33014 University of Tampere

Finland

E-mail: johanna.kujala@uta.fi

Johanna Kujala acts as a professor of management and organization at School of Economics and Business Administration at University of Tampere.

Erika Heiskanen

CEO

Juuriharja Consulting Group Oy

Runeberginkatu 61

FIN-00260 Helsinki

Finland

Email: erika.heiskanen@juuriharja.fi

Erika Heiskanen is a consultant and the CEO of Juuriharja Consulting Group.

\footnotetext{
${ }^{1}$ Corresponding author
} 


\section{Abstract}

Purpose: The purpose of this article is to examine the relationship between the ethical culture of organisations and organisational innovativeness.

Methodology: A quantitative empirical analysis was conducted on the basis of a survey of 147 respondents within the public sector in Finland. A multivariate linear regression analysis was done to examine how the ethical culture of organisations is related to organisational innovativeness.

Findings: A positive link was found in the ethical culture of an organisation and organisational innovativeness: ethical culture was important to behavioural, strategic and process innovativeness. Within the ethical culture of an organisation, the dimension of the congruency of management in particular had an important role in organisational innovativeness.

Research limitations/implications: The data was collected from the public sector, and therefore, future studies from the private sector organisations are needed. The results lend support to previous research arguments for the positive effect of an ethical organisational culture on organisational outcomes, particularly the organisational innovativeness described in this article.

Practical implications: It is suggested that congruency of management, discussability and supportability are the organisational virtues which can most effectively enhance organisational innovativeness, specifically behavioural, strategic and process innovativeness in practice.

Originality/value: The research paper provides empirical evidence on the interrelation between the ethical culture of organisations and organisational innovativeness, evidence which is scarce in existing literature on organisational innovativeness. Thus, the paper helps fill this gap in the literature in the field.

Keywords: Organisational innovativeness, innovation, organisational culture, ethical culture of organisations, ethics

Paper type: Research paper

To cite: Riivari, E., Lämsä, A-M., Kujala, J. \& Heiskanen, E. 2012. The ethical culture of organizations and organisational innovativeness. European Journal of Innovation Management, 15 (3). In press. 


\section{Introduction}

Innovativeness has become the decisive factor in the success or survival of many organisations (Van de Ven, 1986; Nonaka \& Takeuchi, 1995; Quinn, 2000). According to Ahmed (1998), many organisations emphasise the importance of making innovations, many try to make them and only a few succeed in doing so. The reality is that even if innovation is discussed in top management meetings and mentioned in key speeches, the dedication often ends there. Ahmed contends that in reality innovation frightens organisations because it is linked to risk.

In the long run the most innovative organisations will be those which can deal constructively with risk. Researchers suggest that, for example, such elements as autonomy, empowerment, purposefulness, open communication, collaboration, diversity, continuous learning, trust, competitiveness, conflict handling, and leadership commitment are important factors that can promote organisational innovativeness (e.g. Martins and Terblance, 2003; Bassett-Jones, 2005; Ellonen et al., 2008; Rose-Anderssen and Allen, 2008; Miller and Triana, 2009). In general, the values of flexibility as opposed to rigidity, and freedom as opposed to control are stressed in the literature as promoting innovations (Martins and Terblance, 2003).

Along with the demands for innovativeness, it is increasingly recognized in organisations that ethics is crucial to their sustainable performance (e.g. Carroll, 1991; Paine 1997; Solomon, 2004; Crane and Matten, 2007). In the era of globalization, organisations increasingly face conflicts in values and interests and thus need guiding principles and norms to help them meet these complex challenges successfully (Crane and Matten, 2007). Organisational malpractices such as corruption, discrimination, cheating and dishonesty harm not only individuals and societies but also organisations themselves. A lack of attention to ethics in the organisational culture of Enron, for example, was the primary cause of its collapse (Sims and Brinkmann, 2003, 2009).

High ethical standards are important in public sector organisations, which will be our focus on in this study, since these organisations are crucial to the overall functioning and wellbeing of society. For example, good governance in public administration is a key factor to improving 
human development in developing countries (Björk, 2009). In international forums like the World Bank and the United Nations, the importance of public integrity is stressed for prosperity in countries both rich and poor. Honest administration is a pillar of democracy. The results of a survey carried out in the EU reveal that most of the member states have recently introduced value declarations or codes of conduct to promote the ethical standards of public authorities (Moilanen and Salminen, 2007). Legislation is the foundation on which the fundamental principles of good, sustainable administration in public sector organisations are built in many countries around the world.

Legal standards, value statements and codes of conduct are important in providing an official normative framework for public sector organisations. However, building and maintaining organisational integrity is a greater challenge than simply passing laws and making public statements (Paine, 1997). Legal regulations define a minimum level of responsibilities for which organisations can be held accountable (Carroll, 1991) but they are limited as a guide to ethical behaviour, for example, due to their backward orientation. Value statements and codes of conduct for their part are often rather general expressions and could even be considered quite meaningless declarations unconnected to organisational practices (Pučètaitè et al., 2010). Therefore the potential of an organisation's own culture for creating and improving ethics is important (Sinclair, 1993). Organisational culture refers to the values, beliefs, traditions and practices that are shared by an organisation's members. It affects an organisations ability to operate with its stakeholders and is a determinant of how people behave, more or less ethically, in the organisation itself. (Schein, 1985.)

The public sector in many countries is nowadays facing many ethical dilemmas and challenges, and this has led to increasing interest in public sector ethics (e.g. Salminen and IkolaNorrbacka, 2010; Fredrickson and Ghere, 2005; Cooper, 2006; Lawton and Doig, 2006). This growing interest can be regarded as a reaction to global New Public Management reform (e.g. Stensöta, 2010; Webb, 2010), which stresses that effectiveness, efficiency and better quality of services are the aims of current attempts to reform the public sector (Webb, 2010). 
In Finland, which is the context for the data gathered in this article, improving productivity in the public sector is a topical theme. Currently, financial policy and an attempt to limit increasing costs are increasingly limiting the entire public sector (Castells and Himanen, 2004; Julkunen, 2006). Globalization, worldwide economic instability, a fair allocation of resources, privatisation, youth unemployment and preserving cost efficiency are current challenges to the Finnish public sector. These issues are not only ethically loaded but they also require innovativeness from public sector organisations, which must reconsider and adjust their activities.

It seems evident that both ethics and innovativeness will play critical roles in the future challenges facing the public sector, and its organisations need both qualities at the same time. One starting point for this article is that public sector organisations are constantly changing. Due to the many challenges they face it is essential for them to develop both their organisational culture and organisational innovativeness. An ethical organisational culture enables a public sector organisation to operate in a sustainable way, and organisational innovativeness contributes to the ability of the organisation to regenerate itself. Fostering both requires a lot of attention by management and leadership, and conscious actions to create an environment in which the desired targets can emerge and flourish.

Research on the ethical organisational context is represented primarily within two constructs: ethical climate and ethical culture (Treviño and Weaver, 2003; Kaptein, 2008). Ethical climate is understood as those perceptions and aspects that determine what constitutes ethical conduct (Victor and Cullen, 1988), whereas ethical culture is defined as those aspects that stimulate ethical conduct (Treviño and Weaver, 2003; Kaptein, 2008). While organisational culture describes what the organisation ultimately is about, climate pays more attention to individuals' perceptions and feelings about organisational practices and policies than to organisational characteristics (Rentsch, 1990). In the field of organisation ethics prior research has progressed by now to distinguish ethical culture as a distinct phenomenon from ethical climate (Treviño and Weaver, 2003). Although some studies of the ethical culture of organisations exist (e.g. Treviño, 1990; Sinclair, 1993; Treviño et al., 1998; Kaptein, 2008, 2009, 2010, 2011; Huhtala et al., 2011), research on the topic is still in its early phase. The concept has been defined theoretically, and the validity of the construct has been tested empirically (Kaptein, 
2008; Huhtala et al., 2011). Moreover, some empirical studies have been carried out which show that the ethical culture of an organisation stimulates the positive behaviour and wellbeing of its members (e.g. Treviño et al., 1998; Kaptein, 2010; Huhtala et al., 2011). However, much more research, particularly empirical research, is needed about the phenomenon, and this paper takes up the challenge.

Organisational innovativeness has been studied extensively from different perspectives. Literature on the topic usually argues for the importance of creativity and innovation in the success of an organisation. Moreover, the literature contains various prescriptions for organisations and their management to increase creativity and innovativeness (see, e.g. Alencar and Bruno-Faria, 1997; Woodman et al., 1993; Ahmed, 1998; Martins and Terblance, 2003; Välimäki and Lämsä, 2010). However, it is surprising that researchers on the topic rarely discuss ethics although enhancing innovation in an organisation can raise ethical concerns. One exception is the study by Baucus et al. (2008). Based on a literature review the researchers identified different categories of behaviour proffered as a means for fostering creativity and innovation that can raise ethical problems.

According to Baucus et al. (2008), there is an evident lack of attention to ethics within the innovation literature. This gap creates an opportunity for this research to build a bridge between the phenomena. In particular, this research makes a contribution to prior literature by examining empirically the relationship between the ethical culture of organisations and organisational innovativeness in the public sector. This paper seeks to address the following questions: Is there a relationship between organisational innovativeness and the ethical culture of organisations? If there is, what kind of relationship is it? In particular, we examine the relationship of the various dimensions of the ethical culture of organisations to various forms of organisational innovativeness, to find out which parts are positively connected and consequently foster both phenomena.

The article has been organised in the following way. The first section of this paper will discuss the theoretical background of the study and introduce the concepts of the ethical culture of organisations and organisational innovativeness. In the second part we present the method and 
the results of a quantitative empirical study in which the relationship between these two phenomena has been investigated. Finally, we present our discussion and conclusion.

\section{The ethical culture of organisations}

The literature on organisational culture contains several definitions and directions. The current debates on the topic can be traced to the early 1980s, when some popular books attracted attention to the topic (Ouchi, 1981; Pascale and Athos, 1982, Peters and Waterman, 1982; Deal and Kennedy, 1982). Since then researchers have attempted to define the concept, seeking to operationalize it for research purposes. Our overarching objective in this study is not to provide an extensive review of the literature addressing how organisational culture can be understood (see, e.g. Hofstede, 1991; Martin, 1992; Handy, 1993; Cameron and Quinn, 2006). We will nevertheless mention Edgar Schein (1985), who was among the first researcher to define the concept. His definition is also one of the most well-known definitions even today, and we adopt this definition as our starting point. By the concept of organisational culture we mean the basic assumptions and shared meanings that have been created, found or developed in an organisation as it has learned to manage problems related to external adaptation or internal integration. The concept of organisational culture consists of values, beliefs, conventions, traditions and practices that are shared among organisation members. (Schein, 1985.)

As organisational culture includes shared assumptions, it is a broader and deeper construct than organisational climate or work climate, which consists of shared perceptions (Victor and Cullen, 1988). Accordingly, the culture of an organisation has an effect on how the members of the organisation interact and work with each other and with their external stakeholder groups. It also affects the processes and procedures of organisation members and is a more powerful factor than official rules in directing the operation of the organisation (Schein, 1985). Brown (1992) suggests that organisational culture can be a powerful tool for improving performance and the key to organisational development and effective leadership. It is therefore important to be aware of the state of the organisation's ethical culture and its effect on the organisation. 
Ethical organisational culture is defined as those aspects and conventions of organisational behaviour that either encourage the organisation to operate in a sustainable way or deter it from doing so (Kaptein, 2008; Treviño and Weaver, 2003). Ethicality, meaning right, admirable and fair values and practices, is the essence of the culture of an organisation (Paine, 1997; Sinclair, 1993; Treviño, 1990; Treviño and Youngblood, 1990). Ethical culture encompasses the experiences, expectations and presumptions of how the organisation promotes ethical and prevents unethical behaviour (Treviño and Weaver, 2003). Previous studies on the ethical culture of an organisation have measured ethical culture as a one-dimensional construct (Treviño et al., 1998). However, the research has progressed from operationalizing it as a one-dimensional construct to a multidimensional construct specifying its different sub-dimensions (Kaptein, 2008). Since the model developed by Kaptein (2008) is multidimensional in nature offering a validated scale (Kaptein, 2008; Huhtala et al., 2011) for measuring the phenomenon, it is applied in this study.

In this study we define the ethical culture of an organisation drawing upon the Corporate Ethics Virtues Model (CEV), which formulates normative criteria with multiple dimensions for evaluating the ethical culture of organisations (Kaptein, 1998, 2008, 2009, 2010). According to Kaptein (2008), the virtuousness of an organisation can be determined by the extent to which the culture of the organisation stimulates its members to act ethically and prevents them from acting unethically. Kaptein's (2008) model distinguishes eight virtues framed on a virtue-based theory of business ethics (Solomon, 2000, 2004): 1) clarity, 2) congruency of supervisors, 3) congruency of management, 4) feasibility, 5) supportability, 6) transparency, 7) discussability and 8) sanctionability. According to Kaptein (2008, p. 924), the first three virtues "relate to the selfregulating capacity of the organisation, the next two virtues to the self-providing capacity of the organisation, and the last three virtues to the self-correcting or self-cleansing capacity of the organisation".

The first organisational virtue, clarity, relates to expectations concerning the conduct of employees. Kaptein (2008) points out that these expectations should be concrete, comprehensive and understandable. If an organisation does not concern itself with distinguishing between ethical and unethical behaviour, the risk of unethical conduct among its employees increases. It could be argued that an ethical organisation has clear ethical standards that its employees also endorse. 
The second and third organisational virtues relate to congruency: congruency of management and congruency of supervisors. Kaptein (ibid.) points out that if the organisation has clear ethical standards but the management and supervisors of the organisation do not follow these standards, employees are confronted with inconsistent or incongruent signals. If, on the other hand, management behaviour is in line with the expectations of the organisation, employees are also given a clear sign that they must support these shared expectations. This virtue depends on managers and supervisors clearly acting according to the organisation's normative expectations.

The fourth organisational virtue is feasibility. According to Kaptein (2008), it concerns the conditions the organisation creates to enable employees to comply with normative expectations. For example, if employees lack sufficient time, financial resources, equipment, information or authority, the risk of unethical conduct increases. The fifth virtue, supportability, refers to how the organisation helps its employees to meet normative expectations. Employees who feel dissatisfied and demotivated at work are presumably acting unethically. Kaptein (ibid.) considers that mistrust and a hostile work environment make it difficult or even impossible for employees to meet the ethical standards of the organisation. Supportability indicates how far employees identify with and are committed to following the normative expectations of the organisation and how the organisation stimulates and supports such behaviour.

Transparency or visibility in the organisation is the sixth virtue in the CEV model. Kaptein (2008) makes it clear that it is important that employees are aware of the consequences of their actions because otherwise they cannot be responsible for their actions and cannot adapt their conduct to meet what is expected and required of them. Transparency is the degree to which employee conduct and its consequences are perceptible to those who can act upon it, that is colleagues, supervisors, subordinates, and the employees concerned. The seventh virtue, discussability, refers to employees' opportunities to raise and discuss ethical issues. If discussability is of a high level in the organisation, moral dilemmas and unethical behaviour can be openly discussed. Also, when ethical issues can be openly discussed without any fear of repercussions, the security of the organisation is enhanced. Finally, the eighth component of the CEV model is the organisational virtue of sanctionability. It refers to the likelihood of employees being punished for behaving unethically and rewarded for behaving ethically. According to 
Kaptein (ibid.), any toleration of unethical behaviour at the managerial level and lack of sanctions makes unethical conduct acceptable. This must therefore be avoided, and rewards must be given for ethical behaviour.

Previous studies on the ethical culture of organisations have already found that ethical culture has positive effects in an organisation. In their study Treviño et al. (1998) found that there is a positive relationship between ethical culture and ethical behaviour as well as ethical culture and organisational commitment. Kaptein (2011) investigated the influence of the ethical culture of organisations on employee responses to observed wrongdoing. He found that different dimensions of ethical culture are related to different types of intended responses. Several dimensions of ethical culture are negatively related to intended inaction and external whistleblowing and positively related to intended confrontation, reporting to management, and calling an ethics hotline. Huhtala et al. (2011) showed that ethical culture has a direct effect on the occupational well-being of managers: it is positively associated with work engagement and negatively related to ethical strain. Huhtala et al. (ibid.) also found that different dimensions of the ethical culture influence different forms of occupational wellbeing differently. The results from the studies by Kaptein (2011) and Huhtala et al. (2011) may indicate that different dimensions of ethical culture are linked to different forms of organisational innovativeness.

\section{Organisational innovativeness}

The concept of innovation can take many forms: it has been studied in many different disciplines and defined from various perspectives (Damanpour and Schneider, 2006). The classical Schumpeterian definition of innovation states that the commercialization of all new combinations is based on the application of new materials and components, the opening of new markets, the introduction of new processes and new organisational forms (Schumpeter, 1934). Thus, an innovation can be a new product or service, some new production process technology, a new social structure or administrative system, or a new plan or programme pertaining to organisational members. Altogether, organisational innovation is closely linked to change, as organisations use innovations as tools to influence their changing internal or external environments (Damanpour, 1991). In this paper we draw on the suggestion that the foundation of 
innovation is ideas, and that it is ultimately people who develop, carry, and modify ideas (Van de Ven, 1986). Knowledge of what enables and strengthens the innovativeness of members of an organisation is critical (Ellonen et al., 2008).

In this study we apply the concept of organisational innovativeness which, according to Lumpkin and Dess (1996), refers to an organisation's willingness, tendency and ability to engage in and support new ideas, novelties, experimentation and creative processes that may result in innovations. Organisational innovativeness is related to an organisation's objective of being more successful, as ideas are transformed into new or improved products, services or processes (Baregheh et al., 2009). Innovative processes in organisations demand people who are able to collaborate and integrate their expertise (Belbin, 1981; Roberts and Fusfeld, 1981; Van de Ven, 1986). Individual creativity is fundamental to an organisation and is the starting point for innovativeness (Amabile et al., 1996).

In previous studies innovativeness has been often understood as a one-dimensional construct that encompasses idea generation and application behaviour (Scott \& Bruce, 1994). However, since innovativeness is nowadays viewed more often as a multidimensional construct, in this study we conceptualize innovativeness as a multidimensional concept based upon the theoretical model of Wang and Ahmed (2004). According to them, organisational innovativeness is seen as "an organization's overall innovative capability of introducing new products to the market, or opening new markets, through combining strategic orientation with innovative behaviour and process" (p. 303). In their study, Wang and Ahmed (2004) developed and validated an organisational innovativeness construct, which enables the measurement of an organisation's overall innovative capability as a multidimensional phenomenon. Wang and Ahmed's model includes five dimensions: 1) product innovativeness, 2) market innovativeness, 3) process innovativeness, 4) behavioural innovativeness and 5) strategic innovativeness.

According to Wang and Ahmed (2004), the dimension of product innovativeness refers to the newness and essentiality of any new products and services and that they are brought out to customers at the right time. The second dimension, market innovativeness includes the novelty of approaches that organisations embrace to access and reach the targeted customers. For some 
organisations market innovativeness refers to entering a new market and for others it means the adoption of new marketing programmes with existing products or services. The third dimension, process innovativeness refers to the opening of new production methods, new management styles and new technology that can be used to enhance production and management systems. Behavioural innovativeness established by the organisation's members, teams and management encourages the formation of an innovative organisational culture, an inclusive internal interest in new ideas and innovation. The fifth dimension, strategic innovativeness is related to an organisation's ability to achieve determined organisational objectives and its ability to recognize a disparity between its ambitions and existing resources and exploit its limited resources creatively.

According to Wang and Ahmed (2004), innovations become possible when organisational innovativeness is developed. To be successful in this process, an organisational environment that nurtures creativeness and constantly guides members of the organisation to seek new solutions is needed (Ahmed, 1998, Judge et al., 1997; Martins and Terblance, 2003; Välimäki and Lämsä, 2010; Westwood and Low, 2003). It has been suggested that challenges, autonomy, work group support, and supervisory and organisational encouragement are the characteristics of an innovative work environment. Also trust, possibilities to participate, the sharing of information and learning are mentioned as essential factors in creating an innovative organisational culture. (Ellonen et al. 2008; Rebernik and Širec, 2007; Roffe, 1999; Scott and Bruce, 1994; Wang and Ahmed, 2004.) In particular, these factors refer to the virtues of feasibility, supportability, and discussability in the CEV model of the ethical culture of organisations (Kaptein, 2008), suggesting that some virtues may be linked more closely than others to organisational innovativeness.

The link between ethics and innovation has not attracted much research attention. Baucus et al. (2008) made an extensive literature review on innovation and creativity studies and detected from the literature what kinds of issues can cause ethical concerns in innovation. According to their study, such behaviours as high risk taking, breaking rules, challenging authority as well as creating stress and competition can be ethically problematic issues in fostering creativity and innovation. The study did not focus on organisational culture, but rather explored specifically how possible unethical behaviour impacted creating innovation. Baucus et al. (ibid.) concluded 
that researchers should consider studying relationships between ethics and creativity and innovation, since many of the practices intended to develop ethical behaviour may prove useful in generating creativity. Ruppel and Harrington (2000) made a survey among 111 IT managers to test whether "right", "just", and "fair" treatment influences trust within the organisation via communication, and whether trust influences perceptions of commitment and innovation. Their study also applied the construct of ethical work climate by Victor and Cullen (1988). Ruppel and Harrington (2000) concluded that moral management and trust are related to organisational performance in organisations where innovations are desirable.

\section{Method}

\subsection{Sample}

The empirical data of this study were collected by means of a standardised questionnaire used in an Internet survey of Finnish state organisations in March and April 2010. The sample size was 450, out of which 147 responses were completed and returned. The final response rate was 33 per cent.

The questionnaire was sent to the Finnish state treasury's Kaiku specialists. The Kaiku employer services provide different services to government departments. Kaiku specialists are a group of civil servants who as a part of their responsibilities focus on advancing the development of wellbeing and functionality in Finnish state organisations. They offer services for example in vocational rehabilitation, training in occupational wellbeing and risk management. (State Treasury, 2011.) Kaiku specialists work in the field of wellbeing and training in different state organisations. As their work is to develop and support other state organisation units in becoming more effective and successful, seeking information about their evaluations of organisational innovativeness and the ethical culture of organisations is interesting and valuable.

Of the participants, 50 per cent were specialists, 20 per cent managers, 18 per cent employees, and 12 per cent supervisors, and the majority (73 per cent) worked in large state organisations (with over 250 employees). 40 per cent of the participants were men and 60 per cent women, and of the supervisors 40 per cent were women. In April 2010, 51 per cent of the 
employees in Finnish state organisations in general were men and 49 per cent women, so women participants were slightly overrepresented in this study. The average age of the participants was 51 years, with an age range from 28 to 67 . The average age of employees in Finnish state organisations was 45 in April 2010, so the average age of the participants was about six years above average.

The education level of the sample was as follows: 50 per cent of the participants had a Master's degree, 25 per cent a vocational or college degree, 16 per cent a Bachelor's degree, 5 per cent a postgraduate degree, and 4 per cent something other (e.g. upper secondary school education). The education level represented the general educational level of Finnish state organisations quite well (Master's or Bachelor's degrees 65 per cent, vocational or college degrees 29 per cent and secondary school level 6 per cent). The participants had been in working life for an average of 24 years. Of the participants 96 per cent worked full time. 92 per cent of the respondents had permanent employment and 8 per cent were employed temporarily.

\subsection{Measurements}

The questionnaire had three parts: first of all concerning respondents' background information, then measurement scales for the ethical culture of organisations and for organisational innovativeness. There were no open-ended questions in the questionnaire. Nominal level questions were used for the collection of background information, while the items concerning innovativeness and culture were answered using a 6-point Likert scale, on which 1 denoted "strongly disagree" and 6 denoted "strongly agree". The 6-point Likert scale was used in both questionnaires to simplify the answering. Some of the items were negatively worded and later reversed.

The ethical culture of organisations was measured with the Corporate Ethical Virtues questionnaire (CEV; Kaptein, 2008). The structure of the CEV scale for measuring and evaluating ethical culture has been validated and supported by various studies (Kaptein, 1998; Huhtala et al., 2011). In this study we used the same scale as Huhtala et al. (2011), which has been first translated from Dutch into Finnish and later back into Dutch. The CEV scale consists of 58 items, which are classified into eight factors of organisational virtues: feasibility (six items, 
e.g. "In my immediate working environment, I am sometimes asked to do things that conflict with my conscience"), supportability (six items, e.g. "In my immediate working environment, an atmosphere of mutual trust prevails"), transparency (seven items, e.g. "If a colleague does something which is not permitted, my manager will find out about it"), discussability (ten items, e.g. "In my immediate working environment, reports of unethical conduct are handled with caution"), sanctionability (nine items, "In my immediate working environment, people are accountable for their actions"), clarity (ten items, e.g. "The organization makes it sufficiently clear to me how I should conduct myself appropriately toward others within the organization"), congruency of supervisor (six items, e.g. "My supervisor sets a good example in terms of ethical behaviour") and congruency of management (four items, e.g. "The conduct of the Board and (senior) management reflects a shared set of norms and values") (Kaptein, 2008).

First, eight sum variables were produced to test the CEV model. Cronbach's alphas, which are shown in Table I, are above 0.843 , which suggests that all dimensions have relatively high internal consistency.

\section{Insert Table I here}

Also, confirmatory factor analysis was performed to test the fit of the eight-dimensional model using the Amos program. The one-factor solution for ethical organisational culture is shown in Figure I.

\section{Insert Figure I here}

Standardized regression weights and $\mathrm{R}^{2}$-statistics of the one-factor CEV model are shown in Table II.

\section{Insert Table II here}

As can be seen from Figure I and Table II, all eight dimensions load on the common CEV factor. Supportability and discussability appeared to be the best indicators of ethical 
organisational culture. Their standardized regression weights are, respectively, 0.87 and 0.86 , which means that ethical organisational culture explains about 87 per cent of the variance in supportability and 86 per cent of the variance in discussability. Feasibility was the poorest among the indicators of ethical organisational culture, with an $\mathrm{R}^{2}$ of 0.22 and a standardized regression weight of 0.47 .

Organisational innovativeness was measured with a 20-item questionnaire developed and validated by Wang and Ahmed (2004). The original measurement was in English and was first translated by a professional translator into Finnish and later back into English. Four items were asked in each of five groups, each of which focused on one particular factor: product innovativeness (e.g. "Our new products and services are often perceived as very novel by customers"), market innovativeness (e.g. "In new product and services introductions, our organisation is often at the cutting edge of technology), behavioural innovativeness (e.g. "We get a lot of support from managers if we want to try new ways of doing things"), process innovativeness (e.g. "When we cannot solve a problem using conventional methods, we improvise on new methods") and strategic innovativeness (e.g. "Senior executives constantly seek unusual, novel solutions to problems via the use of "idea men").

The original four-factor solution for market innovativeness failed in our study and produced a low alpha (0.236) for the sum variable of market innovativeness. In the analysis of this study, the factor of market innovativeness consists of only three items. As one item of market innovativeness (IN03 "Our recent new products and services have only minor changes from our previous products and services") was deleted, the alpha for this factor improved significantly (alpha 0.518). This might be due to the characteristics of public sector organisations, as they do not necessarily develop and offer new products but rather focus on different kinds of services and target them to well-known customers.

Alphas of the organisational innovativeness dimensions are shown in Table I, and they too have relatively high internal consistency: product innovativeness 0.79; market innovativeness 0.52; behavioural innovativeness 0.90 ; process innovativeness 0.74 and strategic innovativeness 0.89. Confirmatory factor analysis was used to test the five-factor model of organisational 
innovativeness. The one-factor solution for organisational innovativeness, using confirmatory factor analysis with the Amos program, is shown in Figure II.

Insert Figure II here

Standardized regression weights and $\mathrm{R}^{2}$ statistics of the one-factor innovativeness model are shown in Table III.

Insert Table III here

As Figure II and Table III show, all five dimensions load on the common organisational innovativeness factor. Process innovativeness and behavioural innovativeness appeared to be the best indicators of organisational innovativeness. Organisational innovativeness explains about 83 per cent of the variance in process innovativeness and 81 per cent of the variance in behavioural innovativeness. Market innovativeness is the poorest among the indicators of organisational innovativeness, with an $\mathrm{R}^{2}$ of 0.33 and a standardized regression weight of 0.57 .

\section{Results}

\subsection{Correlation analysis}

Table IV presents the correlation matrix of CEV and innovativeness models.

\section{Insert Table IV here}

As the table shows, ethical organisational culture correlated positively with organisational innovativeness $(\mathrm{r}=.56, \mathrm{p}<.001)$. Table I presents the means, standard deviations and Cronbach's alphas of the variables. It also provides a correlation matrix in which ** indicates statistically significant correlation at the 0.01 level and * indicates statistically significant correlation at the 0.05 level. 
The correlation matrix (Table I) shows that ethical organisational culture had a positive correlation with organisational innovativeness so that discussability had a positive correlation with behavioural innovativeness $(r=.65, \mathrm{p}<.001)$, process innovativeness $(r=.54, p<.001)$ and strategic innovativeness $(\mathrm{r}=.53, \mathrm{p}<.001)$. Also congruency of management had a positive correlation with behavioural innovativeness $(\mathrm{r}=.59, \mathrm{p}<.001)$, process innovativeness $(\mathrm{r}=.54, \mathrm{p}$ $<.001)$ and strategic innovativeness $(r=.54, \mathrm{p}<.001)$. Supportability had a positive correlation with behavioural innovativeness $(r=.61, p<.001)$ and process innovativeness $(r=.51, p<.001)$. Also, sanctionability had a positive correlation with behavioural innovativeness: $(r=.59, \mathrm{p}$ $<.001)$.

The correlation matrix in Table I indicates that there are interconnections between ethical organisational culture and organisational innovativeness. The dimensions of ethical organisational culture and organisational innovativeness also correlate significantly with each other.

\subsection{Regression analysis}

The effects of the eight dimensions of the ethical culture of an organisation on the five types of organisational innovativeness were analysed by means of multivariate linear regression analysis. Table V presents models for the regression analysis.

\section{Insert Table V here}

Ethical organisational culture as a one-dimensional model explains 31 per cent of organisational innovativeness (Adj. $\mathrm{R}^{2}$ 0.313; F 67.545). This is presented in Table VI.

\section{Insert Table VI here}

As the regression models in Table $\mathrm{V}$ show, the role of congruency of management in organisational innovativeness seems to be the most important $(\mathrm{p}<0.05)$. In addition, discussability is related to organisational innovativeness, as are transparency and clarity, although not all dimensions of the latter are positively associated. 
According to regression analysis (Table V), the role of ethical organisational culture in behavioural innovativeness was the most important factor as it explained about 48 per cent of behavioural innovativeness (adj. $\mathrm{R}^{2}$ 0.475; $\mathrm{F}$ 17.491). Ethical organisational culture also explained about 33 per cent of strategic innovativeness (adj. $\mathrm{R}^{2} 0.326$; F 9.814) and about 37 per cent of process innovativeness (adj. $\mathrm{R}^{2}$ 0.366; F 11.555). However, the role of ethical culture was not significant for market innovativeness (adj. $\mathrm{R}^{2}$ 0.143; F 4.054) or product innovativeness (adj. $\mathrm{R}^{2}$ 0.229; F 6.419).

\section{Discussion and conclusion}

In general, the respondents in this study gave rather positive evaluations of the ethical culture of their organisations. Of the CEV factors, clarity received the highest evaluation and supportability the lowest. Clarity receiving a high evaluation shows that the ethical standards of public authorities are clear and understandable for Finnish state organisation members. This result implies that communicating about and training in ethical standards in these organisations have been successful (Kaptein, 2009). The comparative study of the public-service ethics of EU member states by Moilanen and Salminen (2007, p. 45) signals a similar idea: the majority of public sector organisations in EU countries stress clear, specific and well-communicated values and standards. However, what is important to note is that the virtue of clarity indicates that the members of an organisation are aware of ethical standards; however, it does not indicate how the standards are followed in practice. Supportability receiving the lowest evaluation among all factors implies that developmental activities in the Finnish state authority should be targeted at how the organisation can stimulate people's behaviour in practice to identify with and commit to ethical expectations. Moreover, the development of trust and respect in the organisation would be valuable.

The results in our study - clarity receiving the highest evaluation and supportability the lowest - parallel the results of Huhtala et al. (2011), who investigated the ethical culture of organisations from the perspective of Finnish managers. In their study only 7.9 per cent of the respondents represented public administration, thus, the majority of the respondents in their 
research represented the private sector. In their research clarity also received the highest score and supportability the lowest score. So, it seems obvious that the strengths and challenges in the ethical culture of organisations are similar for both state and business organisations in Finland. Organisations meet constant changes and challenges stemming from instability in the global economic environment and changes in the operational environment that might have an effect on the evaluations of supportability, as these kinds of challenges easily hinder commitment to and trust in organisations.

Concerning organisational innovativeness, product, process and behavioural innovativeness received the highest scores in our study, while market innovativeness received the lowest score. This study showed that the level of organisational innovativeness in general was lower than the level of ethical culture in public sector organisations. In their study conducted in the information and communication technology (ICT) and paper and pulp industry organisations in Finland, Ellonen et al. (2008) also received the highest scores for process, product and behavioural innovativeness, although they used a four-factor model for organisational innovativeness in which the dimensions of product and market innovativeness were combined into one factor. Although the results are not fully comparable, it seems that product innovativeness, referring to enhancing new production and management systems, process innovativeness, referring to the right timing, and behavioural innovativeness, referring to the organisation's internal interest in new ideas and innovation, were evaluated at the same way in Finnish public and private sector organisations.

In our study, market innovativeness received the lowest score, which might be due to the characteristics of public sector organisations. According to Wang and Ahmed (2004), market innovativeness includes the novelty of approaches that organisations embrace to access and reach targeted customers. It might be that in public sector organisations it is not that essential to focus on marketing and reaching new customers, as the operating environment might be predetermined since public sector organisations usually operate and collaborate with some particular organisations, for example, different state organisations. The Finnish state treasury's Kaiku specialists, who were the informants in this study, provide services to government departments and advance wellbeing and development in Finnish state organisations (State Treasury, 2011). 
Therefore it would be important to investigate the organisational innovativeness in private sector organisations so that comparisons between state and business organisations could be made about different aspects of innovativeness. The study by Ellonen et al. (2008) shows that there might be similarities in organisational innovativeness between public and private sector organisations.

Also, the Kaiku specialists have an important role in the field of promoting wellbeing, training and organisational development. Due to their responsibilities, it can be assumed that they have a good general overview of their organisations. Hence, the respondents in this study may be more conscious in terms of ethics and innovativeness compared to other people working in state organisations. This is a perspective that should be kept in mind while reading the results of this study.

In this study the relationship between the ethical culture of an organisation and organisational innovativeness was found to be positively linked in the public sector: the organisation's ethical culture was important to behavioural, strategic and process innovativeness. Our results lend support to previous arguments for the positive effect of ethical organisational culture on organisational outcomes (Treviño et al., 1998; Huhtala et al., 2011). In this research it was shown that establishing ethical standards and practices can boost behavioural, strategic and process innovativeness in public sector organisations, while in the research by Huhtala et al. (ibid.), in which the same measurement of ethical culture was applied as in this research, the ethical culture of organisations was found to have an effect on the work engagement of managers. Our results give reason to conclude that it pays for public sector organisations to invest in the development of ethical organisational culture when their goal is organisational innovativeness.

As shown in this paper, the virtue of congruency of management has a particularly important role in organisational innovativeness. Kaptein (2008) points out that if an organisation has an ethical policy but the management does not follow it, employees are confronted with inconsistent or incongruent signals. In contrast, if management behaviour is in line with the expectations and norms of the organisation, employees are also given clear signals that they should support these shared expectations. Also, the virtues of discussability and supportability were found to be significant virtues in organisational innovativeness. Discussability allows 
ethical issues to be openly discussed without any fear of repercussions, and supportability refers to how the organisation helps its employees to meet normative expectations and how the organisation stimulates and supports such behaviour.

The meaning of organisational innovativeness and creativity has increased in contemporary organisational life. Organisations need innovativeness as well as innovative personnel to be able to create new products, services and processes and to succeed in the future. It is also important that supervisors and managers in the organisations understand the meaning of innovativeness and creativity (Hautamäki and Oksanen, 2011). From organisational practitioners' point of view, results of this study encourage supervisors and managers of both public and private sector organisations, especially those involved in innovation projects and management, to identify and develop their management practices. Managing ethical values requires specific capabilities and circumstances such as clear rules and instructions, open discussion and support from top management. The same holds for the managing and developing of innovations in organisations, which also requires certain capabilities, for example creativity, challenges and trust, as well as social and technological properties. Drawing upon a suggestion by Schein (1985) we may say that managers can influence the ethical culture of an organisation and organisational innovativeness by communicating effectively their priorities and values in these issues. Moreover, rewarding practices as well as criteria for recruiting, promoting and dismissing people should support the priorities and values of ethics and innovativeness. Since the congruence of management seemed to be a crucial virtue in this study to foster both the ethical culture of an organisation and organisational innovativeness, we suggest that in particular managers' consistency in their statements and actions is essential in the creation of an ethically innovative organisation. Furthermore, this study supports the idea that the importance of the support from the supervisors and management is crucial to both organisational innovativeness and the ethical culture of an organisation.

To sum up, based on our findings we suggest that congruency of management, discussability and supportability are the organisational virtues which can most effectively enhance organisational innovativeness, specifically behavioural, strategic and process innovativeness. Moreover, we suggest that since supportability received the lowest score in the 
respondents' evaluations but appears to have a significant role in organisational innovativeness, emphasis in public sector organisations in Finland should be placed on developing an environment in which this virtue can flourish better than it does now.

\subsection{Limitations and suggestions for further research}

The findings of this study must be viewed bearing in mind the limitations of the study. First, the sample size in this study was 147 (response rate 33 per cent), which we consider to be a limitation. Based on their meta-analysis Baruch and Holtom (2008) recommend that an adequate response rate level is about $35-40 \%$. So, from this point of view, our response rate can be regarded as satisfactory. On the other hand, the respondents in this study represent the profile of the state Kaiku specialists quite well. Second, the data were collected through self-report measures that raise the question of common method biases that cannot be easily controlled. In the future, objective innovativeness, performance and outcome measures could be also collected from organisations and be used in the analysis to increase the reliability of the results. Third, the data used in our study were collected only within public sector organisations. In future, a sample could be collected from both the public and private sectors so that comparisons between them could be made and analysed. Besides, the relationship that was studied in this paper needs further research considering other characteristics of the represented organisations; for example, the size and the different business sectors in which they operate.

Fourth, the cross-sectional design of the study can also be seen as a limitation. Although we assumed that the ethical culture of an organisation reinforces organisational innovativeness, the relationship can also be reciprocal or even reversed. Therefore, our investigation provides mainly descriptive knowledge about the connection between ethical culture and innovativeness. From this perspective, a longitudinal research design would be useful to be able to study the causality between the two phenomena. In the future, a longitudinal research design would be useful, as it would also make it possible to study how the relationship between the ethical culture of organisations and organisational innovativeness develop over time. However, we see that this study is an important opening, as it combines research into both organisational innovativeness and the ethical culture of organisations. So, this study can be regarded as a pilot study for prospective research. 
In conclusion, this study showed a positive link between the ethical culture of an organisation and organisational innovativeness. In the future, a qualitative study could give a richer and more in-depth understanding of this relationship. Still quantitative and qualitative as well as empirical and critical studies are needed to affirm the role of the ethical culture in promoting organisational innovativeness.

\section{References}

Ahmed, P. K. (1998), "Culture and climate of innovation". European Journal of Innovation Management, Vol. 1 No. 1, pp. 30-43.

Alencar, E. M. L. S. and Bruno-Faria, M. F. (1997), "Characteristics of an Organizational Environment Which Stimulate and Inhibit Creativity". Journal of Creative Behavior, Vol. 31 No. 4, pp. 271-281.

Amabile, T. M., Conti, R., Coon, H., Lazenby, J., and Herron, M. (1996), "Assessing the work environment for creativity". Academy of Management Journal, Vol. 39, pp. 1154-1184.

Baregheh, A., Rowley, J. and Sambrook, S. (2009), "Towards a multidisciplinary definition of innovation". Management Decision, Vol. 47 No. 8, pp. 1323-1339.

Baruch, Y. and Holtom, B. C. (2008), "Survey response rate levels and trends in organizational research", Human Relations, Vol. 61 No. 8, pp. 1139-1160.

Bassett-Jones, N. (2005), "The Paradox of Diversity Management, Creativity and Innovation". Diversity Management, Creativity and Innovation, Vol. 14 No. 2, pp. 169-175.

Baucus, M. S., Norton, W. I., Baucus, D. A. and Human, S. H. (2008), "Fostering Creativity and Innovation without Encouraging Unethical Behavior". Journal of Business Ethics, Vol. 81 No. 1, pp. 97-115.

Belbin, M. R. (1981), Management Teams. John Wiley \& Sons, New York.

Björk. K. (2009), Development Strategy for Low Human Development Index Countries. Jyväskylä Studies in Education, Psychology and Social Research 189. University of Jyväskylä, Jyväskylä.

Brown, A. D. (1992), "Organizational Culture: The Key to Effective Leadership and Organizational Development". Leadership and Organization Development Journal, Vol. 13 No. 2, pp. 3-6. 
Cameron, K. S. and Quinn, R. E. (2006), Diagnosing and Changing Organizational Culture: Based on the Competing Values Framework. Jossey-Bass, San Francisco.

Carroll, A. B. (1991), "The Pyramid of corporate social responsibility: Toward the moral management of organizational stakeholders". Business Horizons, Vol. 34, pp. 39-48.

Castells, M. and Himanen, P. (2004), The Information Society and the Welfare State: The Finnish model. Oxford University Press, Oxford.

Cooper, T. L. (2006), The responsible administrator: An approach to ethics for the administrative role. Jossey-Bass, San Fransisco.

Crane, A. and Matten, D. (2007), Business Ethics. Oxford University Press, Oxford.

Damanbour, F. (1991), "Organizational innovation: Meta-analysis of effects of determinants and moderators". Academy of Management Journal, Vol. 26, pp. 555-590.

Damanpour, F. and Schneider, M. (2006). "Phases of the adoption of innovation in organizations: effects of environment, organization and top managers". British Journal of Management, Vol. 17 No. 3, pp. 215-236.

Deal, T. E. and Kennedy, A. A. (1982), Corporate Cultures: The Rites and Rituals of Organizational Life. Addison Wesley, Reading, MA.

Ellonen, R. Blomqvist, K. and Puumalainen K. (2008), "The role of trust in organisational innovativeness". European Journal of Innovativeness, Vol. 11 No. 2, pp. 160-181.

Fredrickson, G. H. and Ghere, G. K. (2005), Ethics in Public Management. M. E. Sharpe, New York.

Handy, C. (1993), Understanding Organizations. Penguin Books, Harmondsworth.

Hautamäki, A. \& Oksanen, K. (2011), "Tulevaisuuden kulttuuriosaajat. Näkökulmia moderniin elämään ja työhön", available at:

http://www.eduskunta.fi/triphome/bin/thw.cgi/trip?\$ $\{$ APPL $\}=\operatorname{erekj} \& \$\{$ BASE $\}=\operatorname{erekj} \& \$\{\mathrm{~T}$ $\underline{\text { HWIDS }\}=0.15 / 1308207015 \_187159 \& \$\{\text { TRIPPIFE }\}=P D F . p d f}($ accessed 17 June 2011)

Hofstede, G. (1991), Cultures and Organizations: software of the mind. McGraw-Hill, London.

Huhtala, M., Feldt, T., Lämsä, A-M., Mauno, S. and Kinnunen, U. (2011), "Does the Ethical Culture of Organisations Promote Managers' Occupational Well-Being? Investigating Indirect Links via Ethical Strain". Journal of Business Ethics, Vol. 101 No. 2, pp. 231-247. 
Judge, W.Q., Fryxell, G.E. and Dooley, R.S. (1997), "The new task of R\&D management: creating goal-directed communities for innovation". California Management Review, Vol. 39 No. 3, pp. 72-85.

Julkunen, R. (2006), Kuka vastaa? Hyvinvointivaltion rajat ja julkinen vastuu. Stakes, Helsinki.

Kaptein, M. (1998), Ethics management: Auditing and developing the ethical content of organizations. Springer, Dordrecht.

Kaptein, M. (2008), "Developing and testing a measure for the ethical culture of organizations: the corporate ethics virtue model". Journal of Organisational Behaviour, Vol. 29 No. 7, pp. 923-947.

Kaptein, M. (2009), "Ethics programs and ethical culture: A next step in unravelling their multifaceted relationship". Journal of Business Ethics, Vol. 89, pp. 261-281.

Kaptein, M. (2010), "The ethics of organizations: A longitudinal study of the U.S. working population". Journal of Business Ethics, Vol. 92 No. 4, pp. 601-618.

Kaptein, M. (2011), "From Inaction to External Whistleblowing: The Influence of the Ethical Culture of Organizations on Employee Responses to Observed Wrongdoing". Journal of Business Ethics, Vol. 98 No. 3, pp. 513-530.

Lawton, A. and Doig, A. (2006), "Researching ethics for public service organizations: The view from Europe". Public Integrity, Vol. 8 No 1, pp. 11-33.

Lumpkin, G. T. and Dess, G. G. (1996), "Clarifying the entrepreneurial orientation construct and linking it to performance". Academy of Management Review, Vol. 21 No. 1, pp. 135-172.

Martin, J. (1992), Cultures in Organizations: Three Perspectives. Oxford University Press, Oxford.

Martins, E. C. and Terblance, F. (2003), "Building organizational culture that stimulates creativity and innovation". European Journal of Innovation Management, Vol. 6 No. 1, pp. 64-74.

Miller, T. and Triana, M. (2009), "Demographic Diversity in the Boardroom: Mediators of the Board Diversity-Firm Performance Relationship". Journal of Management Studies, Vol. 46 No. 5, pp. $755-786$.

Moilanen, T. and Salminen, A. (2007), Comparative Study on the Public-service Ethics of the EU Member States. Research and Studies 1/2007. Ministry of Finance, Helsinki. 
Nonaka, I. and Takeuchi, H. (1995), The knowledge-creating company: How Japanese companies create the dynamics of innovation. Oxford University Press, New York.

Ouchi, W. (1981), Theory Z: how American business can meet the Japanese challenge. AddisonWesley, Reading, MA.

Paine, L. S. (1997), Cases in Leadership, Ethics, and Organizational Integrity. Irwin, Chigago.

Pascale, R.T. and Athos, A.G. (1982), The Art of Japanese Management. Penguin, Harmondsworth.

Peters, T.J. and Waterman, R.H. (1982), In Search of Excellence: Lessons from America's Best Run Companies. Harper \& Row, New York.

Pučètaitè, R., Lämsä, A-M. and Novelskaite, A. (2010),"Building organizational trust in a lowtrust societal context". Baltic Journal of Management, Vol. 5 No. 2, pp. 197-217.

Quinn, J. B. (2000), "Outsourcing innovation: the new engine of growth". Sloan Management Review, Vol. 41, pp. 13-28.

Rebernik, M. and Širec, K. (2007), "Fostering innovation by unlearning tacit knowledge". Kybernetes, Vol. 36 No. 3/4, pp. 406-419.

Rentsch, J. R. (1990), "Climate and Culture: Interaction and Qualitative Differences in Organizational Meanings". Journal of Applied Psychology, Vol. 75 No. 6, pp. 668-681.

Roffe, I. (1999), "Innovation and creativity in organisations: a review of the implications for training and development". Journal of European Industrial Training, Vol. 23 No. 4/5, pp. 224-237.

Roberts, E. B. and Fusfeld, A. R. (1981), "Staffing the Innovative Technology-Based Organization". Sloan Management Review, No. spring, pp. 19-34.

Rose-Anderssen, C. and Allen, P. M. (2008), "Diversity and learning for innovation: dialogue for collaboration". Journal of Management Development, Vol. 27 No. 3, pp. 307-327.

Ruppel, C. P. and Harrington, S. J. (2000), "The Relationship of Communication, Ethical Work Climate, and Trust to Commitment and Innovation", Journal of Business Ethics, Vol. 25, pp. 313-328.

Salminen, A. and Ikola-Norrbacka, R. (2010), "Trust, good governance and unethical actions in Finnish public administration". International Journal of Public Sector Management, Vol. 23, pp. 647-668.

Schein, E. H. (1985), Organizational culture and leadership, 2 ed. Jossey-Bass, San Francisco. 
Schumpeter, J. A. (1934), The Theory of Economic Development. Harvard University Press, Cambridge.

Scott, S. G. and Bruce, R. A. (1994), "Determinants of innovative behavior: a path model of individual innovation in the workplace". Academy of Management Journal, Vol. 37 No. 3, pp. 580-607.

Sims, R. R. and Brinkmann, J. (2003), "Enron Ethics (Or: Culture Matters More than Codes)". Journal of Business Ethics, Vol. 45 No. 3, pp. 243-256.

Sims, R. R. and Brinkmann, J. (2009), "Thoughts and second thoughts about Enron ethics". In Christina Garsten and Tor Hernes (Eds.) Ethical Dilemmas in Management, pp. 105-114. New York: Routledge.

Sinclair, A. (1993), "Approaches to organisational culture and ethics". Journal of Business Ethics, Vol. 12, pp. 63-73.

Solomon, R. C. (2000), "Business with virtue: Maybe next year". Business Ethics Quarterly, Vol. 10 No. 1, pp. 319-331.

Solomon, R. C. (2004), "Aristotle, ethics \& business organisations". Organisation Studies, Vol. 25 No. 6, pp. 1021-1043.

State Treasury. (2011), "Services for government employers, departments and agencies". http://www.statetreasury.fi/public/default.aspx?nodeid=16180 (accessed 17 June 2011).

Stensöta, H. O. (2010), "The Conditions of Care: Reframing the Debate about Public Sector Ethics". Public Administration Review, No: March/April, pp. 295-303.

Treviño, L. K. (1990), "A cultural perspective on changing and developing organisational ethics". Research in Organisational Change and Development, Vol. 4, pp. 195-230.

Treviño, L. K. and Weaver, G. R. (2003), Managing ethics in business organizations: Social scientific perspectives. Stanford University press, Stanford.

Treviño, L. K. and Youngblood, S. A. (1990), "Bad apples in bad barrels: A causal analysis of ethical decision making behavior". Journal of Applied Psychology, Vol. 75, pp. 378-385.

Treviño, L. K., Butterfield, K. D. and McCabe, D. L. (1998). "The Ethical Context in Organisations: Influences on Employee Attitudes and Behaviours". Business Ethics Quarterly, Vol. 8 No. 3, pp. 447-476. 
Välimäki, S. and Lämsä, A-M. (2010), "Critical factors for organizational innovation in the field of diverse human resources". In Schiuma, G., Spender, JC \& Weir, M. (eds.) Conference Proceedings 2010 'International Forum on Knowledge Asset Dynamics', pp. 1-23.

Van de Ven, A. (1986), "Central problems in the management of innovation". Management Science, Vol. 32, pp. 590-607.

Victor, B. and Cullen, J.B. (1988), "The Organizational Bases of Ethical Work Climates". Administrative Science Quarterly, Vol. 33 No. 1, pp. 101-125.

Wang, C. L. and Ahmed, P. K. (2004), "The development and validation of the organizational innovativeness construct using confirmatory factor analysis". European Journal of Innovation Management, Vol. 7 No. 4, pp. 303-313.

Webb, W. (2010), "Public management reform and the management of ethics. Incompatible ideas for the developing state?" International Journal of Public Sector Management, Vol. 23 No. 7, pp. 669-684.

Westwood, R. and Low, D. R. (2003), "The Multicultural Muse: Culture, Creativity and Innovation". International Journal of Cross Cultural Management, Vol. 3 No. 2, pp. 235259.

Woodman, R.W., Sawyer, J.E. and Griffin, R.W. (1993), "Toward a Theory of Organizational Creativity". Academy of Management Review, Vol. 18 No. 2, pp. 293-321. 
Table I Correlation matrix, sum variables

\begin{tabular}{|c|c|c|c|c|c|c|c|c|c|c|c|c|c|c|c|c|c|}
\hline & Mean & SD & $\alpha$ & 1. & 2. & 3. & 4. & 5. & 6. & 7. & 8. & 9. & 10. & 11. & 12. & 13. & 14. \\
\hline 1. CEV & 4,17 & 0,831 & 0,974 & & & & & & & & & & & & & & \\
\hline 2. Innovativeness & 3,35 & 0,792 & 0,907 &, $564^{* *}$ & & & & & & & & & & & & & \\
\hline 3. Feasibility & 4,361 & 0,936 & 0,843 &, $511^{\text {*** }}$ &, $252^{* *}$ & & & & & & & & & & & & \\
\hline 4. Supportability & 3,599 & 1,108 & 0,930 &, $811^{* *}$ &, $545^{* *}$ &, $372^{* *}$ & & & & & & & & & & & \\
\hline 5. Transparency & 3,830 & 0,879 & 0,847 &, $687^{* *}$ &, $422^{* *}$ &, $292^{* *}$ &, $661^{* *}$ & & & & & & & & & & \\
\hline 6. Discussability & 4,136 & 1,051 & 0,951 &, $797^{* *}$ &, $584^{* *}$ &, $347^{* *}$ &, $753^{* *}$ &, $618^{* *}$ & & & & & & & & & \\
\hline 7. Sanctionability & 3,884 & 0,947 & 0,896 &, $800^{* *}$ &, $511^{* *}$ &, $426^{* *}$ &, $673^{* *}$ &, $577^{* *}$ &, $724^{* *}$ & & & & & & & & \\
\hline 8. Clarity & 4,721 & 0,801 & 0,913 &, $669^{* * *}$ &, $405^{* *}$ &, $428^{* *}$ &, $537^{* * *}$ &, $497^{* *}$ &, $550^{* * *}$ &, $517^{* *}$ & & & & & & & \\
\hline 9. Congruency of supervisor & 4,619 & 1,131 & 0,947 &, $660^{* *}$ &, $320^{* *}$ &, $292^{* *}$ &, $549^{* *}$ &, $472^{* *}$ &, $499^{* *}$ &, $540^{* *}$ &, $472^{* *}$ & & & & & & \\
\hline $\begin{array}{l}\text { 10. Congruency of } \\
\text { management }\end{array}$ & 4,279 & 1,187 & 0,921 &, $716^{* *}$ &, $587^{* *}$ &, $464^{* *}$ &, $674^{* *}$ &, $460^{* *}$ &, $623^{* *}$ &, $602^{* * *}$ &, $385^{* *}$ &, $478^{* *}$ & & & & & \\
\hline 11. Product innovativeness & 3,694 & 1,031 & 0,794 &, $405^{* *}$ &, $712^{* *}$ & ,200* &, $407^{* *}$ &, $260^{* *}$ &, $450^{* *}$ &, $335^{* *}$ &, $377^{* *}$ & $205^{*}$ &, $406^{* *}$ & & & & \\
\hline 12. Market innovativeness & 2,676 & 0,832 & 0,518 &, $267^{* *}$ &, $619^{* *}$ & ,109 &, $331^{* *}$ &, $168^{*}$ &, $296^{* *}$ &, $326^{* *}$ & ,133 & ,109 &, $360^{* *}$ &, $387^{* *}$ & & & \\
\hline $\begin{array}{l}\text { 13. Behavioural } \\
\text { innovativeness }\end{array}$ & 3,401 & 1,139 & 0,901 &, $637^{* *}$ &, $783^{* *}$ &, $262^{* *}$ &, $606^{* *}$ &, $459^{* *}$ &, $647^{* *}$ &, $589^{* * *}$ &, $394^{* *}$ &, $375^{* *}$ &, $596^{* *}$ &, $537^{* * *}$ &, $453^{* *}$ & & \\
\hline 14. Process innovativeness & 3,694 & 0,990 & 0,740 &, $563^{* *}$ &, $785^{* *}$ & ,209* &, $511^{* *}$ &, $491^{* *}$ &, $540^{* *}$ &, $480^{* * *}$ &, $384^{* *}$ &, $372^{* *}$ &, $539^{* *}$ &, $659^{* *}$ &, $482^{* *}$ &, $656^{* * *}$ & \\
\hline 15. Strategic innovativeness & 3,293 & 0,893 & 0,645 &, $459^{* *}$ &, $763^{* *}$ &, $266^{* *}$ &, $438^{* *}$ &, $326^{* *}$ &, $534^{* *}$ &, $437^{* *}$ &, $307^{* *}$ &, $342^{* *}$ &, $543^{* *}$ &, $500^{* *}$ &, $467^{* *}$ &, $692^{* *}$ &, $629^{* *}$ \\
\hline
\end{tabular}

\footnotetext{
** Correlation is significant at the 0.01 level (2-tailed). * Correlation is significant at the 0.05 level (2-tailed).
} 
Table II Regression weights and R2's of the one-factor solution for the CEV model

\begin{tabular}{lrr}
\hline & $\begin{array}{c}\text { Standardized } \\
\text { regression } \\
\text { weight }\end{array}$ & $\mathrm{R}^{2}$ \\
\hline Congruency of Supervisor & 0,636 & 0,404 \\
Congruency of Management & 0,735 & 0,540 \\
Feasibility & 0,473 & 0,224 \\
Supportability & 0,870 & 0,756 \\
Transparency & 0,722 & 0,521 \\
Discussability & 0,857 & 0,734 \\
Sanctionability & 0,814 & 0,662 \\
Clarity & 0,639 & 0,408
\end{tabular}


Table III Regression weights and R2's of the one-factor solution for the organisational innovativeness model

\begin{tabular}{lrr}
\hline & $\begin{array}{c}\text { Standardized } \\
\text { regression } \\
\text { weight }\end{array}$ & $\mathrm{R}^{2}$ \\
\hline Product_innovativeness & 0,703 & 0,494 \\
Market_innovativeness & 0,572 & 0,328 \\
Behavioural_innovativeness & 0,811 & 0,658 \\
Process_innovativeness & 0,834 & 0,696 \\
Strategic_innovativeness & 0,785 & 0,616
\end{tabular}


Table IV The correlation matrix of CEV and innovativeness models

\begin{tabular}{lcccc}
\hline Variable & Mean & SD & $\alpha$ & 1 \\
\hline 1. CEV & 4,170 & 0,831 & 0,974 & \\
2. INNOVATIVENESS & 3,354 & 0,792 & 0,907 &, $564^{* *}$ \\
** Correlation is significant at the 0.01 level (2-tailed) & &
\end{tabular}


Table V Regression models

\begin{tabular}{|c|c|c|c|c|c|c|c|c|c|c|c|c|c|c|c|}
\hline $\begin{array}{l}\text { Dimensions of innovativeness } \\
\text { Model fit }\end{array}$ & \multicolumn{12}{|c|}{ Dependent variable } & \multicolumn{3}{|c|}{ Strategic innovativeness } \\
\hline Independent variables & Beta & $T$ & Sig. & Beta & $T$ & Sig. & Beta & $T$ & Sig. & Beta & $T$ & Sig. & Beta & $T$ & Sig. \\
\hline Congruenc & & $-1,314$ & 0,191 & $-0,104$ & $-1,690$ & 0,093 & $-0,060$ & $-0,769$ & 0,443 & 0,004 & 0,056 & 0,956 & 0,036 & 0,519 & 0,605 \\
\hline Congruency of management & 0,205 & 2,167 & $0,032^{*}$ & 0,156 & 2,283 & $0,024 *$ & 0,267 & 3,097 & $0,002 * *$ & 0,288 & 3,497 & $0,001 * *$ & 0,277 & 3,619 & $0,000 * *$ \\
\hline Feasibility & $-0,064$ & $-0,668$ & 0,505 & $-0,074$ & $-1,074$ & 0,285 & $-0,107$ & $-1,217$ & 0,226 & $-0,131$ & $-1,564$ & 0,120 & $-0,006$ & $-0,077$ & 0,938 \\
\hline Discus & & 2,115 & $0,036^{*}$ & 0,006 & 0,070 & 0,945 & 0,313 & 2,726 & $0,007 * *$ & 0,162 & $1,4^{4}$ & & 0,313 & 3,065 & $0,003 * *$ \\
\hline Sanctionability & & $-0,398$ & 0,691 & 0,172 & 1,870 & 0,064 & 0,214 & 1,838 & 0,068 & 0,053 & 0,472 & 0,6 & 0,008 & 0,073 & 0,942 \\
\hline Clarity & 0,308 & 2,469 & $0,015^{*}$ & $-0,027$ & $-0,297$ & 0,767 & 0,045 & 0,392 & 0,696 & 0,118 & 1,082 & 0,281 & 0,010 & 0,100 & 0,92 \\
\hline
\end{tabular}

** Correlation is significant at the 0.01 level * Correlation is significant at the 0.05 level 
Table VI Regression model, CEV and innovativeness

\begin{tabular}{|c|c|c|c|c|}
\hline & $\begin{array}{l}\text { Dependen } \\
\text { Innovative }\end{array}$ & $\begin{array}{l}\text { tvariable } \\
\text { ness }\end{array}$ & & \\
\hline Model fit & $\begin{array}{r}\text { Adj. } \mathrm{R}^{2} \\
0.313\end{array}$ & $\begin{array}{l}\mathrm{F}(\mathrm{df}) \\
67,545^{* *}\end{array}$ & & \\
\hline Independent variable & Beta & $T$ & Sig. & \\
\hline CEV & 0.538 & $8.219 * *$ & & 0.000 \\
\hline
\end{tabular}


Figure I CEV model, one-factor solution

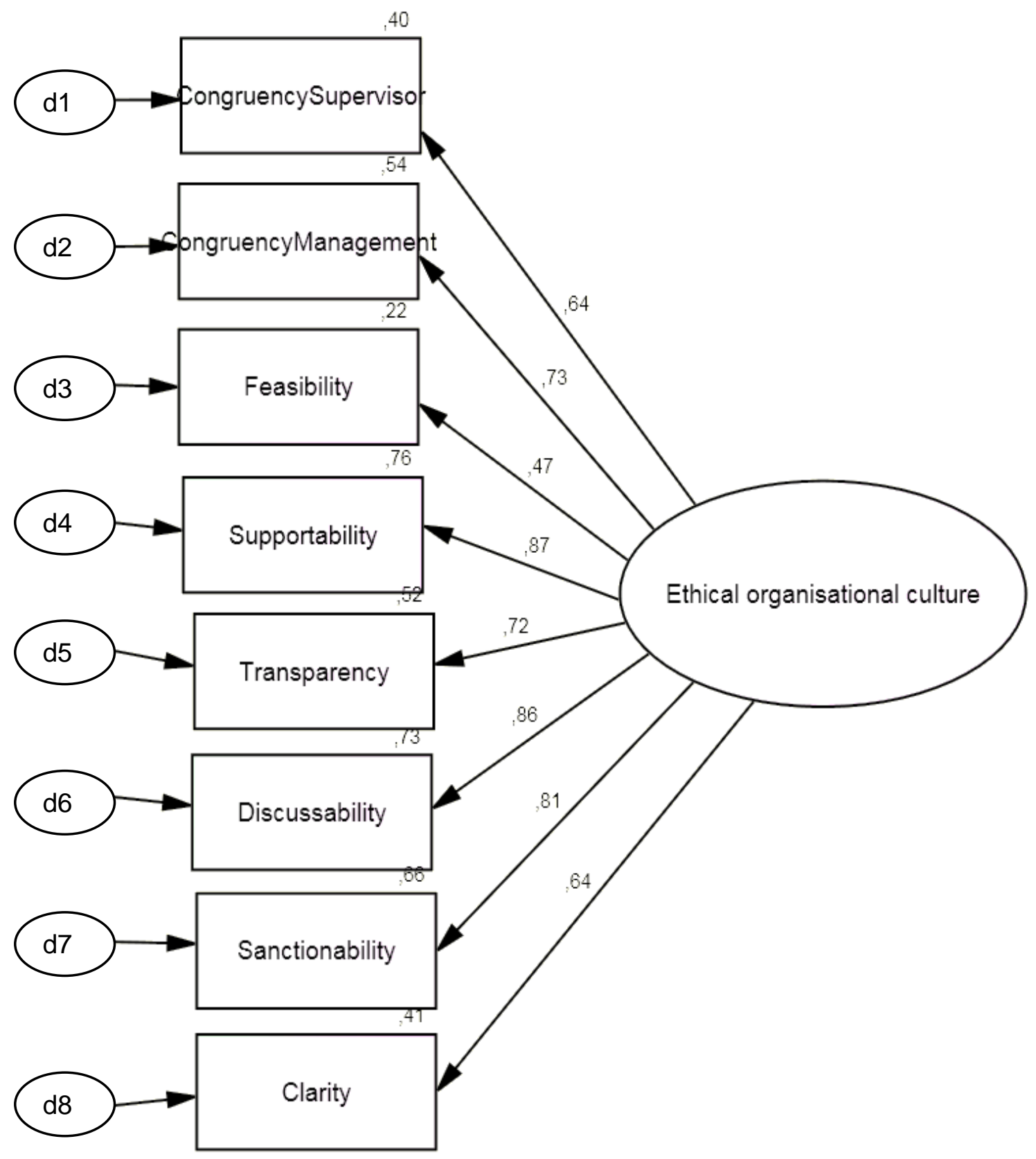


Figure II One-factor solution for organisational innovativeness

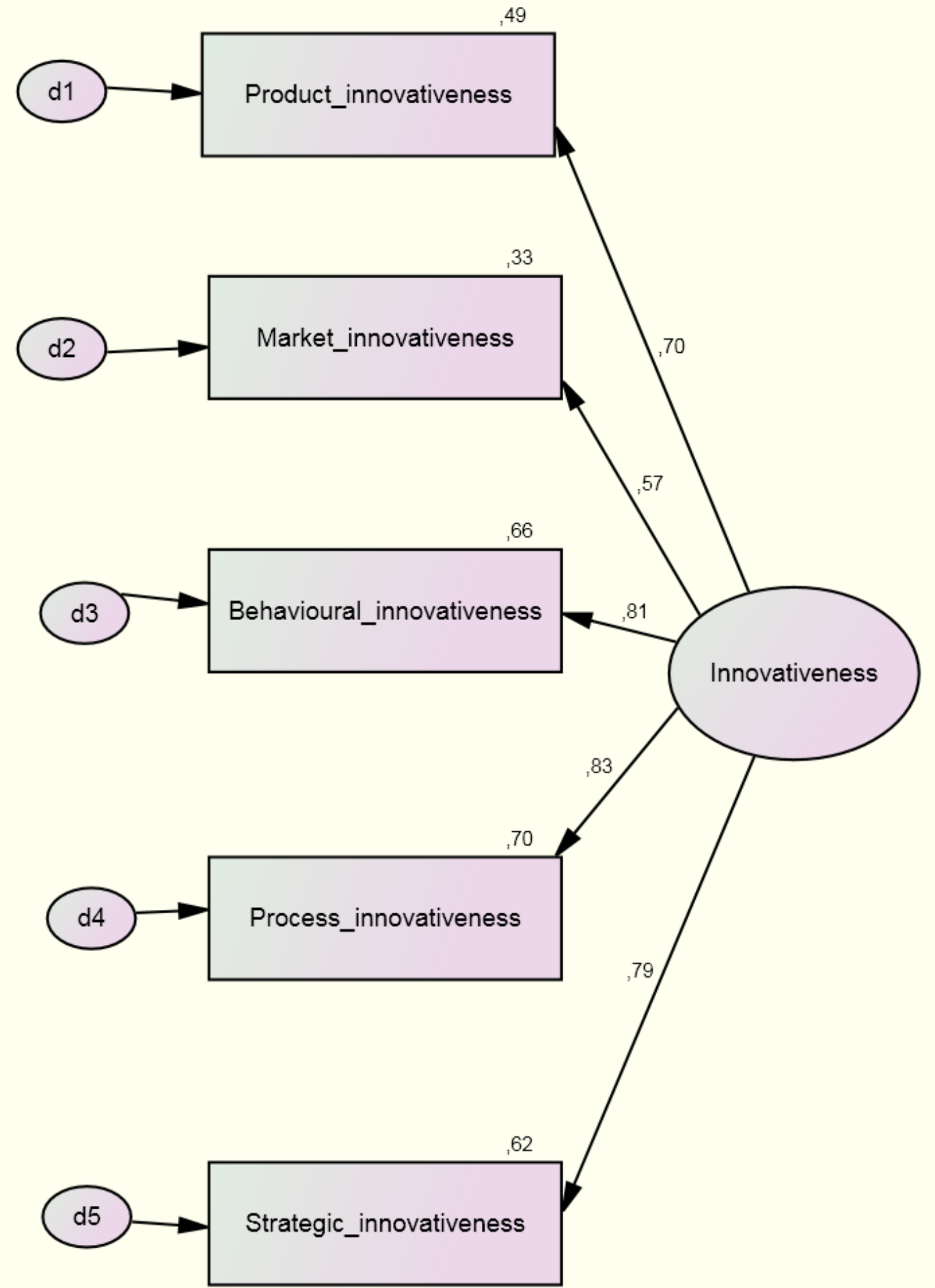

